\title{
立体視表現による覚醒度の増進と車載計器への応用
}

\author{
○河合 隆史, 中村 啓佑（早稲田大学 基幹理工学部）
}

\section{Emotional arousal with stereoscopic representation and the application to car instrument panel}

Takashi KAWAI and Keisuke NAKAMURA

(School of Fundamental Science and Engineering, Waseda University)

\section{1.はじめに}

筆者らは、立体視（3D）表現の感情に及ぼす影 響について、継続的な検討を行ってきた。具体的 には、著名な3D映画に含まれる両眼視差を分析し、 感情毎の特徵的な変化を見出した ${ }^{1)}$ 。また、その 影響の検証を通して、3D画像の奥行き方向の再生 範囲の拡大による、覚醒度の上昇を認めた ${ }^{2-3)}$ 。 さらに最近では、感情画像による覚醒度の増進に 伴う時間知覚の変化 ${ }^{4)}$ 着目し、3D表現による覚 醒度の増進と評価時間の延長傾向について報告し $た^{5)}$ 。評価時間の延長は、内因性の時間感覚

(internal clock) の加速を示唆し、それに伴う 反応時間の変化も知られている

本研究では、3D表現による覚醒度の増進の応用 として自動車の計器を対象に、実験的な検討を 行った。具体的には、ドライバーの覚醒度の増進 手段として奥行き方向に可動する車載計器を表現 し、その効果について2種類の評価実験を行った。

\section{2. 実験 1 : シミュレータによる評価}

ゲーム開発環境（Unity）を用いて市街地を運 転するシミュレータを構築した。自動運転で走行 する状況を想定し、画面下部に車載計器を配置し た。刺激は65インチ偏光フィルタ方式3Dディスプ レイ（ソニー，KD-65X8500B）を用い、約 $120 \mathrm{~cm} の$ 視距離で呈示した（図1）。

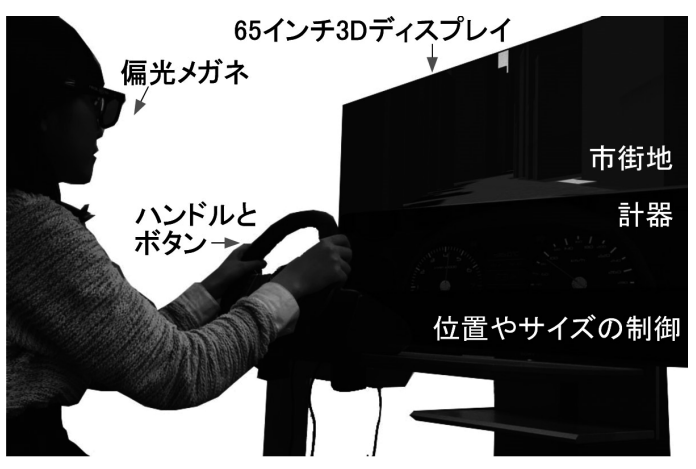

図1 実験系の概要（シミュレータ）
主観評価はSelf-Assessment Manikin (SAM) 7) を用いて情動価と覚醒度を測定した。客観評価で は、他車が走行路に侵入してからハンドルの停止 ボタンを押下するまでの反応時間を計測した。

実験条件は、計器の立体情報（両眼視差とサイ ズ）を操作することで、以下の4種類を設定した。

・統制条件：基準位置に計器を表現

・近方条件：基準位置より近方に表現

・接近条件：近接と拡大を動的に表現

・遠方条件：計器を縮小し遠方に表現

参加者は、正常な視機能を有する19〜24才の男 女18例であり、実験前にインフォームドコンセン 卜を行った。4種類の実験条件と5種類の他車の侵

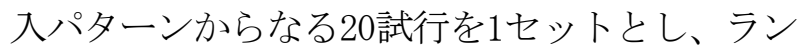
ダマイズして4セットを実施した。

参加者には、10秒間の走行中に他車の侵入を認 めた際のボタンの押下と、その後のSAMーの回答 を試行毎に求めた。

結果から、近方および接近条件において有意な 覚醒度の上昇がみられた（図2）。近方条件では遠 方条件より反応時間が短い傾向が認められた。

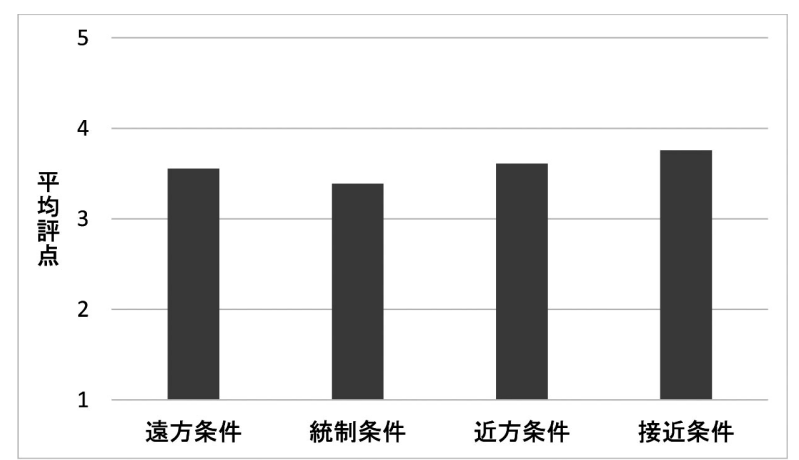

図2 実験 1 覚醒度の結果

\section{3. 実験 2 : 可動計器の試作による評価}

実験 1 で構築したシミュレータの計器部分 を小型の液晶パネルに代替し、マイコンボー 
ド（Arduino）を介してステッピングモータを 制御した。ハンドル前方に可動計器を配置し、 ディスプレイまでの視距離は約 $150 \mathrm{~cm}$ とした (図 3)。

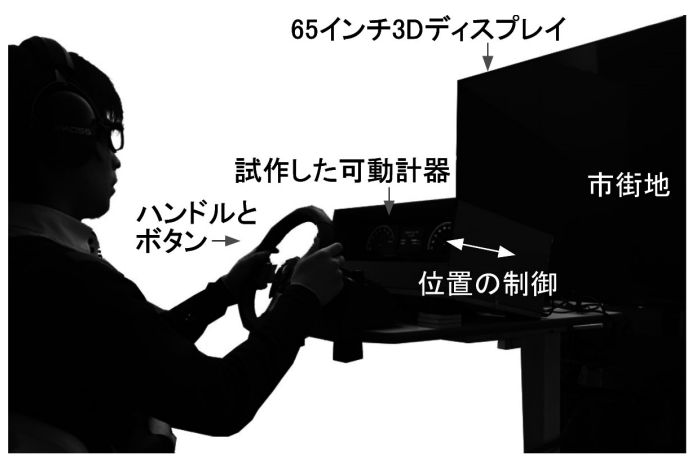

図3実験系の概要（稼働計器）

実験条件は、以下の3種類を設定した。

・統制条件：基準位置に計器を固定

・近方条件：基準位置より近方に固定

・接近条件：計器が動的に近方へ移動

参加者は19〜24才の男女18例であり、その他の 方法は実験 1 と同様であった。

結果から、接近条件において覚醒度の上昇に有 意傾向がみられた（図4）。一方で、近方条件にお いて反応時間の有意な短縮が認められた。

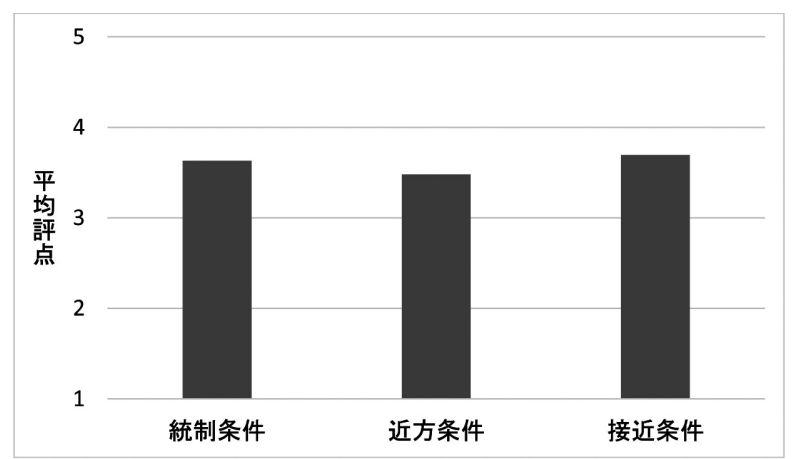

図4 実験 2 覚醒度の結果

\section{4.まとめ}

本研究では、車載計器の3D表現によるドライ バーの覚醒度や反応時間への影響について、実験 的な検討を行った。

2種類の評価実験のいずれにおいても、計器の 接近による覚醒度の上昇が認められた。このこと は、他車の侵入に注意を向けている状況にあって も、視野内の他の物体との距離の変化が覚醒度に 影響し得ることを示唆している。換言すれば、ド ライバーの覚醒度の増進手段として、一定の効果
を期待し得ると考えられた。

しかしながら反応時間については、有意差や傾 向が認められたものの、シミュレータ内の空走距 離に換算すると $1 \mathrm{~m}$ に満たなかった。加えて、近 方・接近条件では情動価の低下がみられたため、 課題や生起される感情の種類などを考慮した上で、 さらなる検討が必要と考えられた。

\section{謝辞}

本研究の推進にあたり、早稲田大学基幹理工学 部の卒業生 浜 理沙子さんの多大な助力を得た。 ここに感謝の意を表す。

\section{参考文献}

1) T. Kawai et al. : "Disparity analysis of 3D movies and emotional representations," SPIE, vol. 8648, pp. 86480Z-1-9, 2013.

2) T. Kawai et al. : "Disparity modifications and the emotional effects of stereoscopic images," SPIE, vol.9011, pp.901115-1-8, 2014.

3) T. Kawai et al. : "Disparity modification in stereoscopic images for emotional enhancement," SPIE, vol.9391, pp. 93910Q-18, 2015.

4) S. Gil, S. Droit-Volet: "Emotional time distortions: The fundamental role of arousal," Cognition \& Emotion, vol.26, no. 5, pp. 847-862, 2012.

5) T. Kawai et al. : "Emotional arousal with 3D images and effects on time perception," Proc. of Electronic Imaging, 2016 (印刷中).

6) L. Rousseau, R. Rousseau: "Stop-reaction time and the internal clock," Perception \& Psychophysics, vol. 58, no. 3, pp.434-448, 1996.

7) M. M. Bradley, P. J. Lang: "Measuring emotion: The self-assessment manikin and the semantic differential," Journal of Behavior Therapy and Experimental Psychiatry, vol. 25, no. 1, pp. 49-59, 1994. 